\title{
THE STUDY OF COMPLEX STRESS STATES OF ELEMENTS FILLING THE CELLS BETWEEN THE RIBS OF WOODEN LARGE-SPAN DOMES
}

\author{
Konstantin P. Pyatikrestovsky, Boris S. Sokolov \\ JSC "Research Centre "Construction", Moscow, RUSSIA
}

\begin{abstract}
The article is devoted to the research of complex stress states of anisotropic materials under long-term loads. The article considers the design of criteria for short-term and long-term strengths proposed by G.A. Geniev in connection with the calculation of large-span structures of domes of laminated and solid wood, where the enclosure elements are included in the joint work with the power set in the form of meridional and circular ribs. In this case, the elements of an enclosure-plate are at a complex stress state and they work under compression with a shift. Joint work of such systems was studied by experiments on large-scale models and experimental construction. Large reserves of strength resistance are revealed. In particular, in 1985, the indoor skating rink at the stadium "Lokomotiv" was built as an experimental facility which implemented these conditions and it has been successfully operated for many years. However, there are some unsolved issues with the refinement of the actual operation of the structures and the development of the calculation algorithm. Some generalizations of the studied approaches are given.
\end{abstract}

Keywords: long-span structures, glued wood, mechanical models of anisotropic material, strength criteria, long-term strength, shifting forces

\section{ИССЛЕДОВАНИЕ СЛОЖНЫХ НАПРЯЖЕННЫХ СОСТОЯНИЙ ЭЛЕМЕНТОВ ЗАПОЛНЕНИЯ ЯЧЕЕК МЕЖДУ РЕБРАМИ БОЛЬШЕПРОЛЕТНЫХ КУПОЛОВ ИЗ ДРЕВЕСИНЫ}

\author{
К.П. Пятикрестовский, Б.С. Соколов \\ Научно-исследовательский центр «Строительство», г. Москва, РОССИЯ
}

\begin{abstract}
Аннотация: Статья посвящена исследованиям сложных напряженных состояний анизотропных материалов при длительных воздействиях нагрузок. Рассматривается построение критериев кратковременной и длительной прочности, предложенное Г.А. Гениевым, в связи с расчетом большепролетных конструкций куполов из клееной и цельной древесины, в которых элементы ограждения включаются в совместную работу с силовым набором в виде меридиональных и кольцевых ребер. При этом элементы ограждения плиты - оказываются в сложном напряженном состоянии и работают при сжатии со сдвигом. Совместная работа таких систем изучалась экспериментально на крупномасштабных моделях и опытном строительстве. Выявлены большие резервы силового сопротивления. В частности, в 1985 году построен экспериментальный объект: крытый каток на стадионе «Локомотив», на котором реализованы указанные предпосылки, и он успешно эксплуатируется много лет. Однако остались некоторые нерешенные вопросы с уточнением действительной работы конструкций и построением алгоритма расчета. Исследуются дощато-гвоздевые плиты различной толщины при длительном воздействии сдвигающих усилий. Даются некоторые обобщения исследуемых подходов.
\end{abstract}

Ключевые слова: большепролетные конструкции, клееная древесина, механические модели анизотропного материала, критерии прочности, длительная прочность, сдвигающие усилия 
Current state of timber building is characterized by mass appliance of large span and tall structures. Domes and similar to dome structures of envelopes are widespread among large span structures and multi-storey residential building, for example 30-storey buildings in Canada, are spread among tall structures. In Russia, currently 4 - 9-storey residential buildings are constructed. The feature of such buildings and structures is appliance of glued wood elements of large cross section and especial internal forces distribution between elements. In some case it is required cross section sizes, which exceed technological possibilities of timber structure plants, and it leads to use structures like trusses.

However, there are another possibilities to decrease cross section sizes, which are provided by designing of statically undetermined systems of high order of indetermination that leads to joint work of neighbor elements that is to creation of spatial structures. In this case such system allows plastic deformations and has property to redistribute internal forces that gives economic effect based on the material consumption decreasing.

There is a system of meridional and ring ribs in spatial structures like a dome. The cells between ribs can be filled by envelope structures such a shield, panel or brace. At the same time, the elements, filling these cells, work at complex stress state (compression, tension and shear), if the ribs are subjected stresses action as it is inherent to linear structures.

Calculation of such structures linked with some troubles and requires introduction of strength theories and criteria that can be incomprehensible for specialists of design institutions.

There are a large number theoretical and experimental investigation of wood strength at twodimensional stress states, for example [1-7] and etc. The majority of authors, which are classic today, recognize that such theories are hard to practical appliance.

G.A. Geniev [2, 8-10] devoted many years to develop practically applicable strength criteria for different materials.

Despite the main provisions for Geniev strength criteria are published $[2,10,11]$, let us present in the paper derivation of long term strength criterion for anisotropic material and example of it usage, and apply such criterion to investigate two-dimensional stress state of envelopes of a large span dome.

\section{Mechanical and physical models of long term strength for anisotropic material.}

The mechanic model of anisotropic material is presented in Figure 1. This one gives analytical and quantitative performance of long term and dynamic strength on the basis of general physical concept in the wide range of load action time, from a few days or several months to tenth or hundredth part of second.

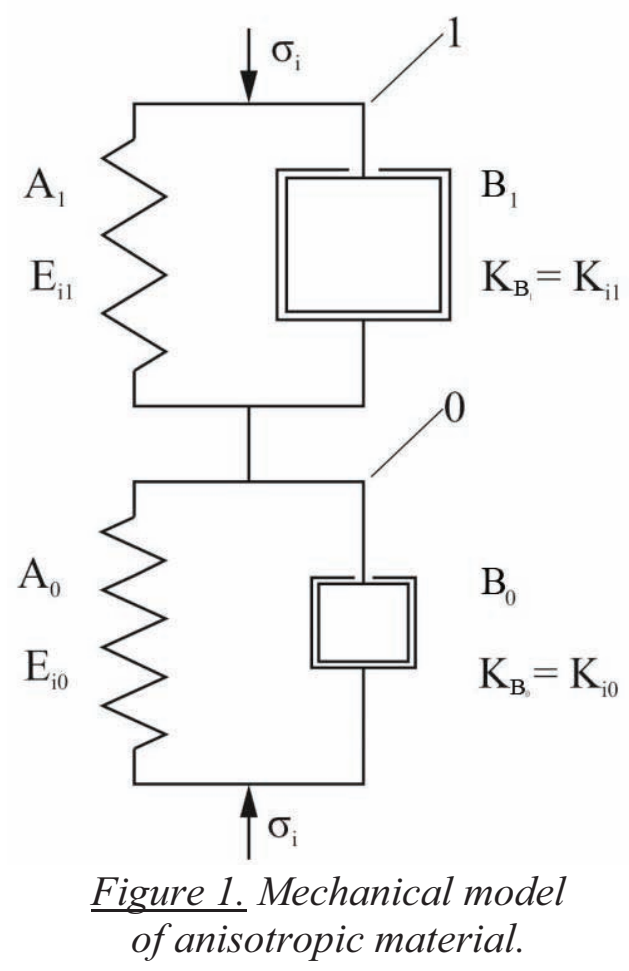

The model consists of two elements connected in series and signed in figure 1 as 0 and 1. Each element represents by Kelvin-Voigt model of parallel connected elements $\mathrm{A}_{0}$ and $\mathrm{B}_{0}, \mathrm{~A}_{1}$ and $\mathrm{B}_{1}$, which are characterized by different values of strength and deformation parameters.

The element signed in figure 1 as 0 is intended to represent analytically the process of material quick time deformation; element signed in fig- 
ure 1 as 1 is intended to represent long time deformation, linked with creep.

Components $A_{0}$ and $A_{1}$ correspond to elastic deformation of material. Components $\mathrm{B}_{0}$ and $\mathrm{B}_{1}$ correspond to viscous properties only. Rigidity of $\mathrm{B}_{1}$ element significantly exceed that one of $\mathrm{B}_{0}$, that is the modulus of viscous resistance $\mathrm{K}_{\mathrm{B} 1}$ exceed modulus $K_{B 0}$ by several orders: $K_{B}>>$ $\mathrm{K}_{\mathrm{B} 0}$. At impact of resultant external force $\sigma_{i}$ to mechanical model, including elements 0 and 1 , where $\mathrm{i}=\mathrm{x}, \mathrm{y}$ are main axes of anisotropy, the effective time of element $\mathrm{B}_{0}$ work continues during small part of second. However during this little time range $\left(t_{0}\right)$ the element $B_{0}$ promotes to decrease force value, which acts to element $A_{0}$ (parts of $\sigma_{i}$ ), and decrease intensity of deformation developing of $\mathrm{A}_{0}$, that determines fact of dynamic strength exceeding of strength obtained during standard experiments, when duration is measured by minutes.

Effective time of $\mathrm{B}_{1}$ element work is commensurate with large time range, corresponding to calculations of long time strength, taking into account accumulation of resultant deformations of 0 and 1 elements during adjusted time $t_{d}$.

There are not any mathematical difficulties at analytical representation of mechanical model of material work.

However, from practice position, it is more expedient the divided approach to determine long term and dynamic strength of anisotropic material, since time ranges $t_{d}$ and $t_{0}$ take values of different orders. Really, at determining of long term strength (time scale $\mathrm{t}_{0}$ ), the element $\mathrm{B}_{0}$ work practically do not influence to result, and at determining of dynamic strength (time scale $t_{d}$ ) the element 1 work cannot be occurring during this time range.

In this way, it is expedient to apply the following modification of general mechanical model of material, presented in figure 1. At determination of long term strength, it is necessary to exclude element $\mathrm{B}_{0}$ from element 0 , using $\mathrm{A}_{0}$ element connected in series with element 1 , as it is shown in figure 2 . And at determination of dynamic strength it is necessary to exclude element 1 entirely using only element 0 , that con- sists of parallel connected elements $\mathrm{A}_{0}$ and $\mathrm{B}_{0}$, as it is shown in figure 3 .

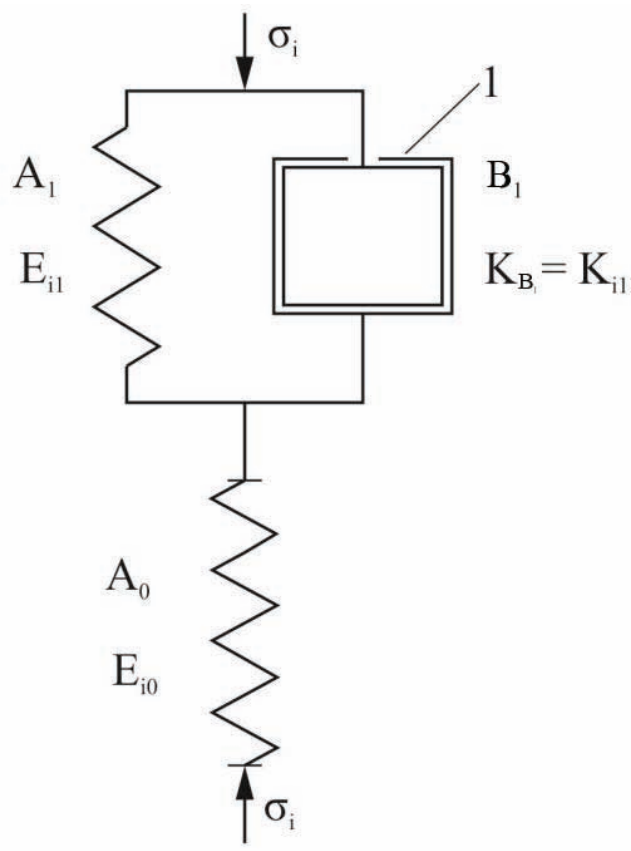

Figure 2. Long term strength mechanical model.

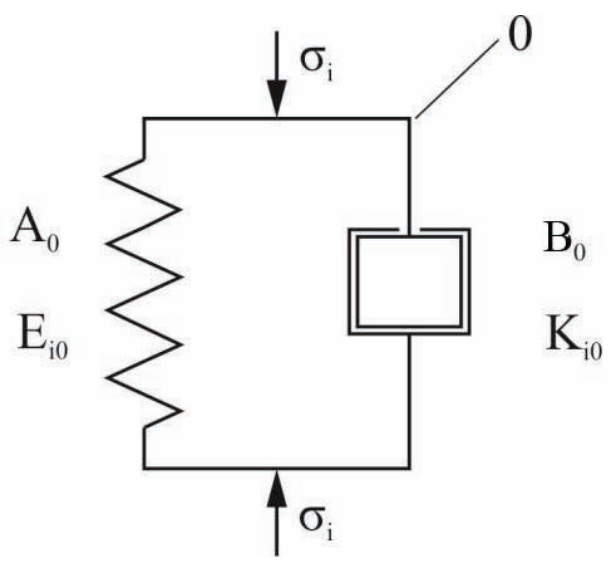

Figure 3. Dynamic strength mechanical model.

The long term and dynamic strength criteria for anisotropic material such as wood, which are obtained in the paper, are formulated for finite elementary material volume, subjected to homogenous complex two-dimensional stress state.

\section{Short term strength criteria of anisotropic ma- terial.}

In accordance with [2] and [9], three independent mechanisms of anisotropic material destruction are possible. It is tear (tension), crumpling 
(compression) and shear, realization of which depends on the type of stress state at reviewing point of solid. These mechanisms may occur at short term action of external loading, that corresponds to time of standard experiments, as well as at long term and dynamic loading action.

One of the main features of the ultimate states of anisotropic materials is difference between dangerous plane orientation for tear, crumpling and shear cases and directions of main normal stresses and greatest tangential stresses in general case.

In accordance with it, the criteria of short term strength for anisotropic material, obtained in the papers [2] and [9], are derived on the basis of the following obvious premises:

- for tear case

$$
\frac{d}{d \varphi}\left[\sigma_{n}(\varphi)-R_{p}(\varphi)\right]=0
$$

- for crumpling case

$$
\frac{d}{d \varphi}\left[\sigma_{n}(\varphi)+R_{c}(\varphi)\right]=0
$$

- for shear case

$$
\frac{d}{d \psi}\left[\tau_{m}(\psi)-R_{c o}(\varphi)\right]=0
$$

where $\sigma_{n}(\varphi)$ and $\tau_{m}(\psi)$ are normal and tangential stresses acting at dangerous planes of tear, crumpling and shear, the direction of which are determined by unknown angles $\varphi$ and $\psi ; R_{p}(\varphi)$, $R_{c}(\varphi)$ and $R_{c \partial}(\psi)$ are absolute values of ultimate normal and tangential stresses at tear, crumpling and shear, obtained from experiments at action of one-dimensional tension, compressive and shear stresses as angle functions of $\varphi$ and $\psi$. Wherein

$$
\left.\begin{array}{l}
\sigma_{n}(\varphi)=\frac{\sigma_{x}+\sigma_{y}}{2}+\frac{\sigma_{x}-\sigma_{y}}{2} \cos 2 \varphi \\
+\tau_{x y} \sin 2 \varphi \\
\tau_{m}(\psi)=\frac{\sigma_{x}-\sigma_{y}}{2} \sin 2 \psi \\
-\tau_{x y} \cos 2 \psi,
\end{array}\right\}
$$

where $\sigma_{\mathrm{x}}, \sigma_{\mathrm{y}}, \tau_{\mathrm{xy}}$ are normal and tangential stresses, acting along main anisotropy directions (along and across fibers in wood), $\varphi$ and $\psi$ are angles between axis $\mathrm{X}$ and normal to planes, as well as

$$
\left.\begin{array}{l}
R_{p}(\varphi)=R_{p x} \cos ^{2} \varphi+R_{p y} \sin ^{2} \varphi ; \\
R_{c}(\varphi)=R_{c x} \cos ^{2} \varphi+R_{c y} \sin ^{2} \varphi ; \\
R_{c o}(\psi)=C_{x} \cos ^{2} \psi+C_{y} \sin ^{2} \psi ;
\end{array}\right\}
$$

where $R_{p x}, R_{p y}$ are values of short term ultimate strength at tear along axis $\mathrm{X}$ and $\mathrm{Y}$ (along and across fibers);

$R_{c x}, R_{c y}$ are values of short term ultimate strength at crumpling along axes $\mathrm{X}$ and $\mathrm{Y}$;

$C_{x}$ and $C_{y}$ are values of short term ultimate strength at shear along planes, the normal of which coincide with axes $\mathrm{X}$ and $\mathrm{Y}$.

On the basis of theses presented above and derivations the following analytical relationships for short term strength criteria of anisotropic materials are obtained in the papers [2] and [9]:

- for tear case

$$
\left(R_{p x}-\sigma_{x}\right)\left(R_{p y}-\sigma_{y}\right)-\tau_{x y}^{2}=0,
$$

- for crumpling case

$$
\left(R_{c x}+\sigma_{x}\right)\left(R_{c y}+\sigma_{y}\right)-\tau_{x y}^{2}=0,
$$

- for shear case

$$
\left(\sigma_{x}-\sigma_{y}\right)^{2}-4\left(C_{x}+\tau_{x y}\right)\left(C_{y}-\tau_{x y}\right)=0 .
$$


Long term strength criteria for anisotropic material

As it is outlined above, it is expedient to use mechanical model presented in figure 2 to determine long term strength of anisotropic materials.

At applying of resultant external long term force to connected in series elements 0 (A0) and 1 (A1, B1), the integral resultant deformations take the form

$$
\begin{gathered}
\varepsilon_{i}=\varepsilon_{i 0}+\varepsilon_{i 1} ; \\
\left(\begin{array}{l}
\varepsilon_{x}=\varepsilon_{x 0}+\varepsilon_{x 1}, \\
\varepsilon_{y}=\varepsilon_{y 0}+\varepsilon_{y 1}, \\
\varepsilon_{x y}=\varepsilon_{x y 0}+\varepsilon_{x y 1}
\end{array}\right) .
\end{gathered}
$$

Separate ultimate strength values (at tear, crumpling and shear) are determined at reaching by resultant deformations values $\varepsilon_{\mathrm{i}}$ it corresponding ultimate ones $-\ni_{i 0} \rightarrow\left(\ni_{x 0}, \ni_{y 0}, \ni_{x y 0}\right)$, that equals to ultimate deformations of $\mathrm{A}_{0}$ element at short term external load acting

$$
\begin{gathered}
-\Im_{i 0}=\frac{R_{i}}{E_{i 0}}: \\
\Im_{x 0}=\frac{R_{x}}{E_{x 0}} ; \Im_{y 0}=\frac{R_{y}}{E_{y 0}} ; \ni_{x y 0}=\frac{R_{x y}}{E_{x y 0}}
\end{gathered}
$$

where

$$
R_{x}=R_{p x} \text { or } R_{c x}, R_{y}=R_{p y} \text { or } R_{c y}, R_{x y}=C_{x} \text { or } C_{y} ;
$$

$E_{x 0}, E_{y 0}$ and $E_{x y 0}$ are linear elastic modulus of $\mathrm{A}_{0}$ element through the directions $X$ and $Y$ (along and across fibers) and it generalized shear modulus respectively.

Element 1 deformations $\varepsilon_{i 1}$ are determined on the basis of the following obvious relations

$$
\begin{gathered}
\sigma_{i}=\sigma_{i A 1}+\sigma_{i b 1} ; \\
\sigma_{i A 1}=E_{i 1} \varepsilon_{i 1} ; \sigma_{i b 1}=K_{i 1} \frac{d \varepsilon_{i 1}}{d t},
\end{gathered}
$$

where $E_{i 1}$ is the generalized elastic modulus of $\mathrm{A}_{1}$ element, $\mathrm{K}_{\mathrm{i} 1}$ is viscous resistance modulus of $\mathrm{B}_{1}$ element. On the basis of (11) we obtain

$$
\begin{aligned}
& \frac{d \varepsilon_{i 1}}{d t}+\frac{E_{i 1}}{K_{i 1}} \varepsilon_{i 1}=\frac{\sigma_{i}}{K_{i 1}}, \\
& \text { and a } t=0, \varepsilon_{i 1}=0- \\
& \varepsilon_{i 1}=\frac{\sigma_{i}}{E_{i 1}}\left(1-e^{-\omega_{i 1} t}\right), \omega_{i 1}=\frac{E_{i 1}}{K_{i 1}} .
\end{aligned}
$$

Thus, in accordance with (9) we obtain:

$$
\varepsilon_{i}=\frac{\sigma_{i}}{E_{i 0}}\left[1+\delta_{i}\left(1-e^{-\omega_{i 1} t}\right)\right]=\frac{\sigma_{i}}{E_{i 0}} \Psi_{i}(t),
$$

where

$$
\delta_{i}=E_{i 0} / E_{i 1} .
$$

In accordance with (10) and (13), the long term strength ultimate values of anisotropic material through main anisotropy direction take the form $\bar{R}_{i}=\bar{R}_{i}\left(\bar{t}_{\partial}\right)$ :

$$
\begin{aligned}
& \bar{R}_{i}=\sigma_{i}=\frac{E_{i 0} \varepsilon_{i}}{\Psi_{i}\left(t_{\partial}\right)}=\frac{E_{i 0} \ni_{i 0}}{\Psi_{i}\left(t_{\partial}\right)}=\frac{R_{i}}{\Psi_{i}\left(t_{\partial}\right)} ; \\
& \bar{R}_{x}=\frac{R_{x}}{\Psi_{x}\left(t_{\partial}\right)} ; \\
& \bar{R}_{y}=\frac{R_{y}}{\Psi_{y}\left(t_{\partial}\right)} ; \\
& \bar{R}_{x y}=\frac{R_{x y}}{\Psi_{x y}\left(t_{\partial}\right)},
\end{aligned}
$$

where

$$
\begin{aligned}
& \Psi_{x}\left(t_{\partial}\right)=1+\delta_{x}\left(1-e^{-\omega_{x 1} t_{\partial}}\right)>1 ; \\
& \Psi_{y}\left(t_{\partial}\right)=1+\delta_{y}\left(1-e^{-\omega_{y 1} t_{\partial}}\right)>1 ; \\
& \Psi_{x y}\left(t_{\partial}\right)=1+\delta_{x y}\left(1-e^{-\omega_{x y 1} t_{\partial}}\right)>1,
\end{aligned}
$$

and $t=t_{\partial}$ is adjusted ultimate time of external long term load action. 
Thus, long term strength of anisotropic material determination linked with changing or rather decreasing of short term strength values through main anisotropy directions in accordance with relationships (14) and (15). Introducing (14) into (6), (7), (8), we obtain finally the relationships for long term strength criteria of anisotropic material related with parameter $t_{\partial}$ : - for tear case

$$
\left[\frac{R_{p x}}{\Psi_{p x}\left(t_{\partial}\right)}-\sigma_{x}\right]\left[\frac{R_{p y}}{\Psi_{p y}\left(t_{\partial}\right)}-\sigma_{y}\right]-\tau_{x y}^{2}=0,
$$

- for crumpling case

$$
\left[\frac{R_{c x}}{\Psi_{c x}\left(t_{\partial}\right)}+\sigma_{x}\right]\left[\frac{R_{c y}}{\Psi_{c y}\left(t_{\partial}\right)}+\sigma_{y}\right]-\tau_{x y}^{2}=0,
$$

- for shear case

$$
\begin{gathered}
\left(\sigma_{x}-\sigma_{y}\right)^{2}- \\
-4\left[\frac{C_{x}}{\Psi_{x y}\left(t_{\partial}\right)}+\tau_{x y}\right]\left[\frac{C_{y}}{\Psi_{x y}\left(t_{\partial}\right)}-\tau_{x y}\right]=0
\end{gathered}
$$

Criteria (16), (17), (18) (besides short term ultimate strength $R_{p x}, R_{p y}, R_{c x}, R_{c y}, C_{x}, C_{y}$ ) include three non-dimensional parameters

$$
\delta_{x}=\frac{E_{x 0}}{E_{x 1}} ; \delta_{y}=\frac{E_{y 0}}{E_{y 1}} ; \delta_{x y}=\frac{E_{x y 0}}{E_{x y 1}},
$$

and three dimensional values $\omega_{\mathrm{i} 1}\left(\sec ^{-1}\right)-$

$$
\omega_{x 1}=E_{x 1} / K_{x 1}, \omega_{y 1}=E_{y 1} / K_{y 1}, \omega_{x y 1}=E_{x y 1} / K_{x y 1}
$$

Numerical values $\delta_{\mathrm{i}}$ and $\omega_{\mathrm{i} 1}$ are determined on the basis of experimental data. The results of $\delta_{\mathrm{i}}$ and $\omega_{\mathrm{i} 1}$ determination for wood are presented in the paper below

Presented criteria of long term strength (16), (17), (18) allows to obtain the $\lambda$ parameter value, corresponding a fracture mechanism of anisotropic material, on the basis of relations be- tween stresses $\sigma_{x}: \sigma_{y}: \tau_{x y}$ and accepted time of long term load action $t_{\partial}$. Inverse problem formulation is determination $t_{d}$ values on the basis of accepted values of $\lambda \rightarrow\left(\lambda_{0}, \lambda_{c}, \lambda_{c \partial}\right)$.

Determination of characteristics, applying at calculation of long term strength of wood, is carried out in [10] on the basis of G.A. Geniev proposals for anisotropic materials. The results of experimental studies of long term resistance of spruce wood, provided by N.L. Leontiev from 1950 to 1955 , are used in the paper $[15,16]$.

Experimental data, characterizing decreasing percent of spruce wood ultimate strength in comparison with corresponding values of ultimate short term strength $\bar{R}_{i}\left(t_{\partial}\right)$, obtained in accordance with load action time $t_{\partial}$, measuring in days, are presented in figure 5 (a), (b), (c).

For all three types of spruce wood resistance, the relationships

$$
\bar{R}_{p x}\left(t_{\partial}\right) / R_{p x}, \bar{R}_{c x}\left(t_{\partial}\right) / R_{c x}, \bar{R}_{x y}\left(t_{\partial}\right) / R_{x y}
$$

at $t_{\partial} \rightarrow \infty$ (at practically non limited load action time) with enough accuracy order it appears equal to 0.5 , that is, maximum decreasing of long term strength is $50 \%$ from short term one. It allows to evaluate values of $\delta_{x}$ and $\delta_{x y}$ parameters on the basis of [17] as well as reviewed experimental result $\left(\Psi_{x}(\infty)=\Psi_{x y}(\infty)=1 / 0,5=\right.$ 2), that is

$$
\delta_{x}=\delta_{x y}=1
$$

Below, the value of resistance across to fibers $\delta_{y}$ accepted equal to 1 .

Analytical approximation of wood long term resistance graphs allows to determinate the following values of $\omega_{x 1}$ :

$$
\begin{aligned}
& - \text { at tension }-\omega_{x 1}=1,65 \cdot 10^{-3} \text { cyт }^{-1} \\
& - \text { at compression }-\omega_{x 1}=2,50 \cdot 10-3 \text { cyт. }^{-1} \\
& - \text { at chopping }-\omega_{x y 1}=7,25 \cdot 10-3 \text { cyт. }^{-1}
\end{aligned}
$$

Values $\omega_{\mathrm{y} 1}$ at resistance across fibers in accordance with significant creep influence in this 
main direction of anisotropy $\left(K_{y 1}<K_{x 1}\right)$ are accepted equal to:

- at tension $-\omega_{y 1}=3,30 \cdot 10^{-3}$ days $^{-1}$,

- at compression $-\omega_{y 1}=5,00 \cdot 10-3$ days $^{-1}$

- at shear $-\omega_{x y 1}=7,25 \cdot 10-3$ days $^{-1}$.

Let us to present numerical example of wood long term strength determination at following values of it strength parameters corresponding to time of short term (standard) tests:

$$
\begin{aligned}
& R_{p x}=14.4 \mathrm{MPa}, \quad R_{\mathrm{py}}=2.4 \mathrm{MPa}, \\
& R_{c x}=22.8 \mathrm{MPa}, \quad R_{c y}=3.8 \mathrm{MPa}, \\
& C_{x}=19.2 \mathrm{MPa}, \quad C_{y}=6.4 \mathrm{MPa} .
\end{aligned}
$$

Let us to carried out calculation of long term strength at the following times

$t_{\partial}=150$ days, $t_{\partial}=300$ days,

$$
t_{\partial}=1000 \text { days and } t_{\partial} \rightarrow \infty \text {. }
$$

At the case of simple (proportional) loading, the stress values along main anisotropy directions $\sigma_{x}, \sigma_{y}, \tau_{x y}$ are:

$$
\sigma_{x}=\lambda \xi_{x}, \sigma_{\mathrm{y}}=\lambda \xi_{y}, \tau_{x y}=\lambda \eta_{x y}
$$

where $\xi_{x}: \xi_{y}: \eta_{x y}$ are accepted relations between stress values, $\lambda$ is parameter of long term external load.

Substituting relationships (24) into criteria of long term strength $[10,12]$ and solving it for $\lambda$, we obtain three following quadratic equation for $\lambda=\lambda_{0}$ values (tear case), $\lambda=\lambda_{c}$ (crumpling case) and $\lambda=\lambda_{\text {sh }}$ (shear case):

$$
\begin{aligned}
& \left(\xi_{x} \xi_{y}-\eta_{x y}^{2}\right) \lambda_{0}^{2}- \\
& -\left[\frac{R_{p x}}{\Psi_{p x}\left(t_{\partial}\right)} \xi_{y}+\frac{R_{p y}}{\Psi_{p y}\left(t_{\partial}\right)} \xi_{x}\right] \lambda_{0}+ \\
& +\frac{R_{p x} R_{p y}}{\Psi_{p x}\left(t_{\partial}\right) \Psi_{p y}\left(t_{\partial}\right)}=0
\end{aligned}
$$

$$
\begin{aligned}
& \left(\xi_{x} \xi_{y}-\eta_{x y}^{2}\right) \lambda_{c}^{2}+ \\
& +\left[\frac{R_{c x}}{\Psi_{c x}\left(t_{\partial}\right)} \xi_{y}+\frac{R_{c y}}{\Psi_{c y}\left(t_{\partial}\right)} \xi_{x}\right] \lambda_{c}+ \\
& +\frac{R_{c x} R_{c y}}{\Psi_{c x}\left(t_{\partial}\right) \Psi_{c y}\left(t_{\partial}\right)}=0 ; \\
& {\left[\frac{\left(\xi_{x}-\xi_{y}\right)^{2}}{4}+\eta_{x y}^{2}\right] \lambda_{c \partial}^{2}+} \\
& +\frac{\left(C_{x}-C_{y}\right)}{\Psi_{x y}\left(t_{\partial}\right)} \eta_{x y} \cdot \lambda_{c \partial}-\frac{C_{x} C_{y}}{\Psi_{x y}^{2}\left(t_{\partial}\right)}=0 .
\end{aligned}
$$

Let us to accept relation between stresses equal to:

that is

$$
\xi_{x}: \xi_{y}: \eta_{x y}=2:(-1): 1,
$$

$$
\begin{gathered}
\xi_{x}=2 \text { (tension along fibers) } \\
\xi_{y}=-1 \text { (compression across fibers) } \\
\eta_{x y}=1
\end{gathered}
$$

(shear in plane formed by main axes $x, y$ ).

In accordance with (20), (21), (22) it is obtained:

$$
\begin{aligned}
& \Psi_{p x}(150)=1.2192 ; \Psi_{p y}(150)=1.3904 ; \\
& \Psi_{c x}(150)=1.3127 ; \Psi_{c y}(150)=1.5276 ; \\
& \Psi_{x y}(150)=1.6629 ; \Psi_{p x}(300)=1.3904 ; \\
& \Psi_{p y}(300)=1.6284 ; \Psi_{c x}(300)=1.5276 ; \\
& \Psi_{c y}(300)=1.7769 ; \Psi_{x y}(300)=1.8864 ; \\
& \Psi_{p x}(1000)=1.808 ; \\
& \Psi_{p y}(1000)=1.9631 ; \Psi_{c x}(1000)=1.9179 ; \\
& \Psi_{c y}(1000)=1.9933 ; \Psi_{x y}(1000)=1.9993 ; \\
& \Psi_{p x}(0)=\Psi_{p y}(0)=\Psi_{c x}(0)= \\
& =\Psi_{c y}(0)=\Psi_{x y}(0)=1 ; \\
& \Psi_{p x}(\infty)=\Psi_{p y}(\infty)=\Psi_{c x}(\infty)= \\
& =\Psi_{c y}(\infty)=\Psi_{x y}(\infty)=2 .
\end{aligned}
$$

The values $\lambda_{0}, \lambda_{c}, \lambda_{s h}$ presented in Table 1 are obtained from equations (25-27). The reduced values of these ones, presented in Table 1, are obtained from relationships 
The Study of Complex Stress States of Elements Filling the Cells Between the Ribs of Wooden Large-Span Domes

Table 1. Parameters.

\begin{tabular}{|c|c|c|c|c|c|c|}
\hline $\begin{array}{c}t_{\partial} \\
\text { days }\end{array}$ & $\begin{array}{c}\text { Tear } \\
\lambda_{0}\end{array}$ & $\begin{array}{c}\text { Crumpling } \\
\lambda_{c}\end{array}$ & $\begin{array}{c}\text { Shear } \\
\lambda_{s h}\end{array}$ & $\begin{array}{c}\text { Tear } \\
\Psi_{0}\end{array}$ & $\begin{array}{c}\text { Crumpling } \\
\Psi_{c}\end{array}$ & $\begin{array}{c}\text { Shear } \\
\Psi_{s h}\end{array}$ \\
\hline 0 & 5.3523 & 3.4079 & 4.4873 & 1 & 1 & 1 \\
\hline 150 & 4.3489 & 2.2551 & 2.6985 & 0.8125 & 0.6617 & 0.6014 \\
\hline 300 & 3.8064 & 1.9387 & 2.3788 & 0.7112 & 0.5689 & 0.5301 \\
\hline 1000 & 2.9427 & 1.7146 & 2.2444 & 0.5498 & 0.5031 & 0.5002 \\
\hline$\infty$ & 2.6762 & 1.7039 & 2.2437 & 0.5 & 0.5 & 0.5 \\
\hline
\end{tabular}

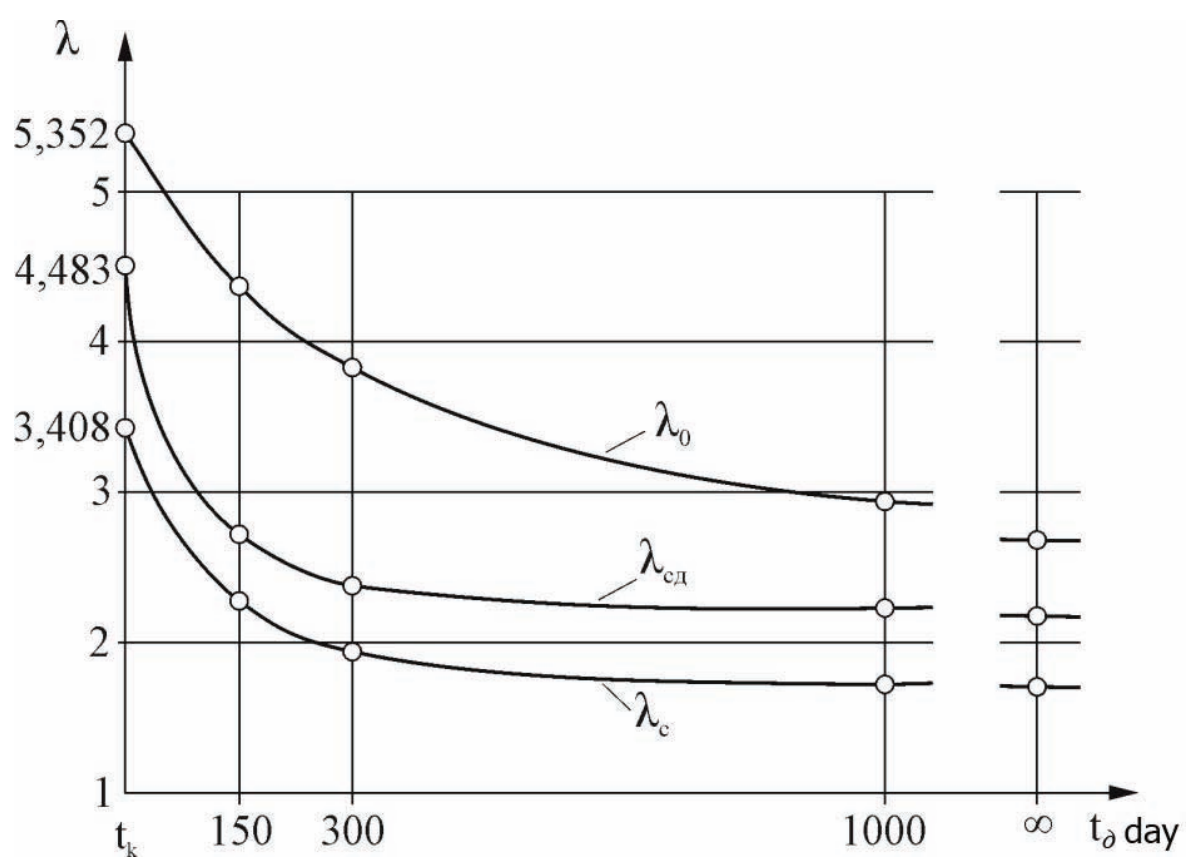

Figure 4. Graphs of external loading parameters $\lambda_{0}, \lambda_{c}, \lambda_{\text {sh }}$ changing in time, obtained by table 1.

$$
\Psi_{0}=\frac{\lambda_{0}\left(t_{\partial}\right)}{\lambda_{0}(0)}, \Psi_{c}=\frac{\lambda_{c}\left(t_{\partial}\right)}{\lambda_{c}(0)}, \Psi_{c \partial}=\frac{\lambda_{c d}\left(t_{\partial}\right)}{\lambda_{c \partial}(0)},
$$

which explicitly characterize material long term strength changing in time.

Thus, at all values of $t_{d}$ we obtain:

$$
\lambda_{\mathrm{o}}>\lambda_{c \partial}>\lambda_{c}
$$

that is, in the reviewed example external load parameter takes the smallest value, that corresponds to wood destruction caused by crumpling (values $\lambda_{c}$ in table 1).

Wherein, the values of ultimate stresses acting along main anisotropy directions are:

$$
\begin{aligned}
& \sigma_{x}(150)=8.6978 \mathrm{M \Pi a}, \sigma_{y}(150)= \\
& =-2.2551 \mathrm{MPa}, \tau_{x y}=2.6985 \mathrm{MPa} ; \\
& \sigma_{x}(300)=7.7548 \mathrm{MPa}, \sigma_{y}(300)= \\
& \quad=-1.9387 \mathrm{MPa}, \tau_{x y}=2.9387 \mathrm{MPa} ; \\
& \sigma_{x}(1000)=3.4292 \mathrm{MPa}, \sigma_{y}(1000)= \\
& =-1.7146 \mathrm{MPa}, \tau_{x y}=1.7146 \mathrm{MPa} .
\end{aligned}
$$

The graphs of relations between parameters of external loading $\lambda_{0}, \lambda_{c}, \lambda_{s h}$ and time $t_{d}$, obtained in accordance with table 1 data are presented in figure 4.

It should be noted that

$$
\psi_{0}>\psi_{c}=\psi_{s h},
$$

that is, relative (reduced) values of external loading parameter for shear case $\psi_{\text {sh }}$ are changed (decrease) in time greater than $\psi_{c}$. 


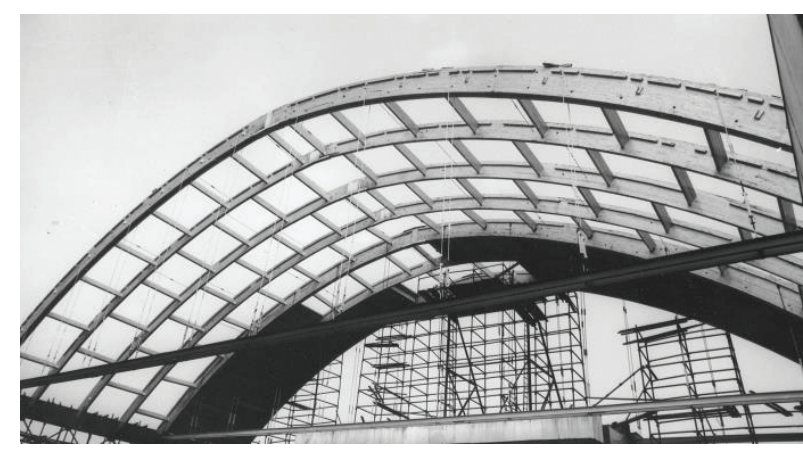

Figure 5. Assembling of short cylindrical shell of $42 \mathrm{~m}$ span.

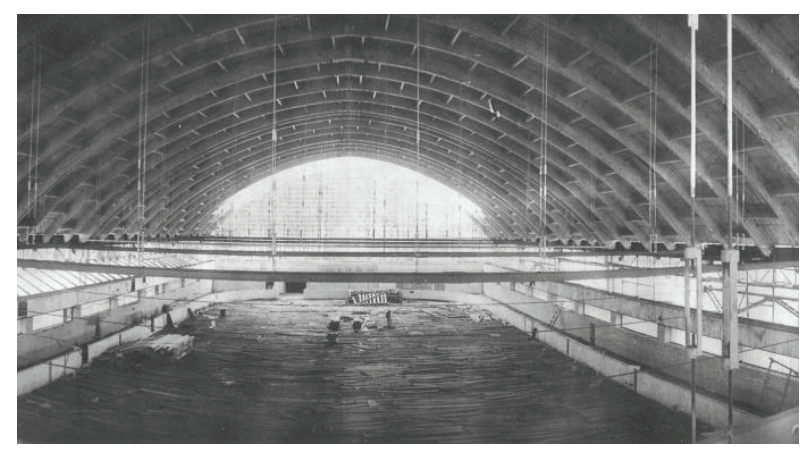

nails quantity at two nails placing in each intersection of planks equals to $19^{2} \cdot 2=722$. At shield shift, caused by shear, nails cause wood crumpling at contact zone. Bearing capacity of it is determined in accordance with codes $T=$ $0.8 a \cdot d \cdot n=0.8 \cdot 4 \cdot 0.3 \cdot 722=693 \mathrm{kN}$.

Here $d$ is nail diameter $(\mathrm{cm}), a$ is shield thickness, $n$ is nail quantity.

Shear stresses at maximum shift after PC computation are

$$
\begin{gathered}
\tau=\frac{\sum T}{b \cdot l}=\frac{693}{\begin{array}{c}
0.04 \cdot 2.49 \\
=6.96 \mathrm{MPa} .
\end{array}}=6957.8 \mathrm{kN} / \mathrm{m}^{2}= \\
\end{gathered}
$$

Obtained value of tangential stress $\tau$ is significantly exceed calculation strength even against chopping across fibers $0.8 \mathrm{MPa}$. In accordance with computation, provided in the paper [11], such shear stress can be reached at $38^{\text {th }}$ stage only at loading $28 \mathrm{kPa}$ and integral exposure during 2580 days ( 7 years).

Let us present computation results corresponding to 27th stage of loading at $6 \mathrm{kPa}$ and initial exposure during 1980 days (5.42 years) at constant load acting from one side. In this way, the maximum compressive stress is $1.45 \mathrm{MPa}$. At load value $2 \mathrm{kPa}$ it takes value $0.5 \mathrm{MPa}$.

It is carried out calculations of reviewed dome at another sizes and thickness of shields to compare. At $2 \mathrm{~cm}$ thickness and $2 \mathrm{kPa}$ loading the maximum stresses are equal to $2.43 \mathrm{MPa}$, and at $8 \mathrm{~cm}$ thickness and such loading the stress values decrease to $1.0 \mathrm{MPa}$. 


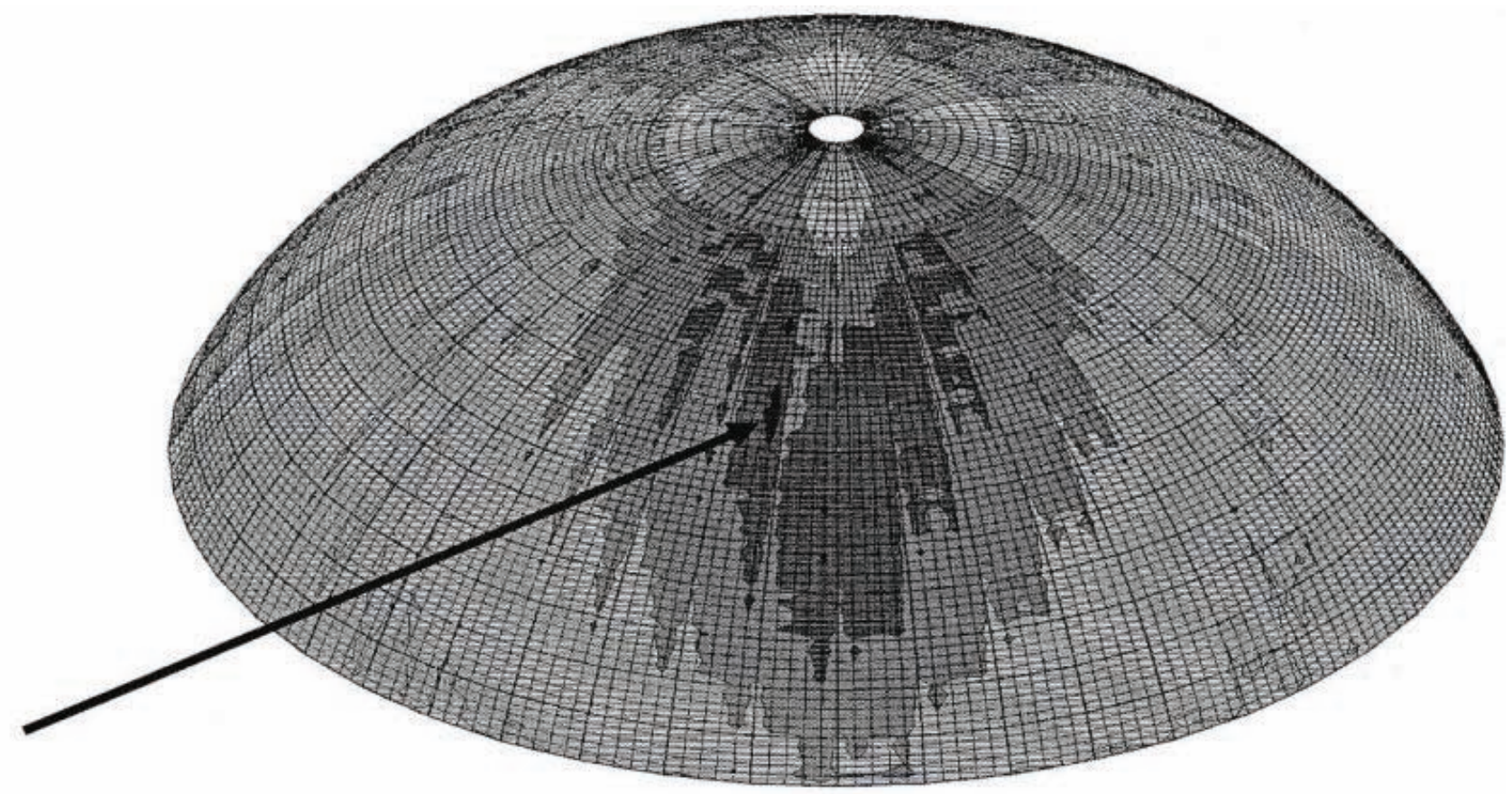

Figure 6. Maximum shear stresses zone.

It is seen, that instead plank shields it can be applied filling by composite material of high strength and small thickness as well as of porous materials of low thermal conductivity.

Construction can resist against load of high intensity during long time at meridional ribs of reduced height of cross section to $1 / 60$ dome diameter. It shows that dome provides high order of structural safety and can be applied to erect structure, operating at hard condition of environmental and technogenic impacts.

\section{CONCLUSIONS}

Currently it is required new approaches to develop designing codes, that should take in account complex stress states and contain proposals to effective computation by PC. At the same time, it necessary to simplify techniques of calculation and apply simple strength criteria. It is expedient to provide row of experimental investigations for two and three-dimensional loading to effective applying of reviewed criteria. It is required to develop new generation designing codes, such as it was carried out 1950th, when ultimate state calculation method was introduced.

Simplifying of PC computation can be reached by automation of the most stressed sections searching, when at each iteration step and deformation modulus correction provides at one section only, and parameters of other section corresponds to linear relationship or parabola in accordance with moment distribution along structure.

Also, there are some problems that requires of experimental investigations at large scale or natural samples. At first, it deals with increasing accuracy of shear stresses distribution between own shear resistance of elements and supporting parts and connections resistance.

\section{REFERENCES}

1. Ashkenazi E.K. Prochnost' Anizotropnykh Drevesnykh i Sinteticheskikh Materialov [Strength of Anisotropic and Synthetic Materials]. Moscow, Lesnaya promyshlennost', 1966, 166 pages (in Russian).

2. Geniev G.A. O Kriterii Prochnosti Drevesiny pri Ploskom Napryazhennom 
Sostoyanii [About Wood Strength Criterion at Two-Dimensional Stress State]. // Stroit. Mekhanika i Raschet Sooruzhenij, 1981, No. 3, pp. 15-20 (in Russian).

3. Gol'denblat I.I. Kopnov V.A. Kriterii Prochnosti i Plastichnosti Konstruktsionnykh Materialov [Strength and Plasticity Criteria of Construction Materials]. Moscow, "Mashinostroenie", 1968, 191 pages (in Russian).

4. Ezepov G.G. Prochnost' Drevesiny pri Dvukhosnom Napryazhennom Sostoyanii. Diss. Kand. Tekhn. Nauk [Wood Strength at Two-Dimensional Stress State. Thesis of Cand. Sci. in Tech.]. Moscow, 1986, 142 pages (in Russian).

5. Orlovich R.B., Ezepov G.G., Najchuk A.YA. K Otsenke Nekotorykh Kriteriev Prochnosti Anizotropnykh Tel pri Ploskom Napryazhennom Sostoyanii [Evaluation of Strength Criteria for Anisotropic Solids at Plane Stress State]. // Tekhnika, Tekhnologiya, Organizatsiya i Ehkonomika Stroitel'stva: Respublikanskij Mezhvedomstvennyj Sbornik. - Vypusk 10: Stroitel'naya Mekhanika i Stroit. Konstruktsii. Minsk: Vyshejshaya shkola, 1984, pp. 124-127 (in Russian).

6. Pyatikrestovskij K.P., KHunagov KH.S. Pereraspredelenie Usilij V Ehlementakh Shatrovoj Obolochki iz Drevesiny i Fanery pri Nesimmetrichnykh Nagruzkakh [Stress Redistribution into Elements of Wood and Plywood Shells in the Form of Tent at NonSymmetric Loadings]. // V Knige "Issledovaniya i Metody Rascheta Stroitel'nykh Konstruktsij". Moscow, TSNIISK im. V. A. Kucherenko, 1985, pp. 40-49 (in Russian).

7. Flakserman A.N. Vliyanie Naklona Volokon na Mekhanicheskie Svojstva Drevesiny Sosny [Fiber Slope Influence to Mechanical Properties of Pine Wood]. // Tr. TSAGI, Vyp. 78, GONTI, Moscow Leningrad, 1931, pp. 48 (in Russian).

8. Geniev G.A., Kurbatov A.S. O Predel'nykh Prochnostnykh Zavisimostyakh dlya anizotropnykh materialov pri sdvige [Ultimate strength relations for anisotropic materials at shear] // Metody rascheta i optimizatsii stroitel'nykh konstruktsij na EHVM. - M.: TSNIISK im. Kucherenko, 1990. - pp. 60-67 (in Russian).

9. Geniev G.A., Kurbatov A.S., Samedov F.A. Voprosy Prochnosti i Plastichnosti Anizotropnykh Materialov [Issues on Strength and Plasticity of Anisotropic Materials]. Moscow, Interbuk, 1993, 187 pages (in Russian).

10. Geniev G.A., Pyatikrestovskij K.P. Voprosy Dlitel'noj i Dinamicheskoj Prochnosti Anizotropnykh Konstruktsionnykh Materialov [Issues on Long Term and Dynamic Strength of Anisotropic Materials]. Moscow, GUP TSNIISK im. V.A. Kucherenko, 38 pages (in Russian).

11. Pyatikrestovskij K.P., Sokolov B.S. Nelinejnyj Raschet Staticheski Neopredelimykh Derevyannykh Konstruktsij i Optimizatsiya Razmerov Sechenij Reber Kupolov [Nonlinear Calculation of Statically Undefined Wood Structures and Cross Section Optimization for Dome Ribs]. // Sb. tezisov VII Mezhdunarodnogo Simpoziuma "Aktual'nye Problemy Komp'yuternogo Modelirovaniya Konstruktsij i Sooruzhenij”, Novosibirsk, 2018 (in Russian).

12. Pyatikrestovskij K.P. Raschet Rebristykh Prostranstvennykh Konstruktsij iz Drevesiny i Fanery na Dlitel'nye Nagruzki [Calculation of Wood and Plywood Spatial Ribbed Structures at Long Term Loadings]. // Stroitel'naya Mekhanika i Raschet Sooruzhenij, 2008, No. 5, pp. 42-48 (in Russian).

13. Leont'ev N.L. Uprugie Deformatsii Drevesiny [Elastic Deformations of Wood]. Moscow, Goslesbumizdat, 1952, 120 pages.

14. Leont'ev N.L. Dlitel'noe Soprotivlenie Drevesiny [Long Term Resistance of Wood]. Moscow - Leningrad, 1957, 132 pages.

15. Zajtsev YU.V. Modelirovanie Deformatsij i Prochnosti Betona Metodami Mekhaniki Razrusheniya [Concrete Deformation and 
Strength Modelling by Fracture Mechanics Methods]. Moscow, "Strojizdat", 1982, 160 pages.

\section{СПИСОК ЛИТЕРАТУРЫ}

1. Ашкенази Е.К. Прочность анизотропных древесных и синтетических материалов. - М.: Лесная промышленность, 1966. - $166 \mathrm{c}$.

2. Гениев Г.А. О критерии прочности древесины при плоском напряженном состоянии. // Строительная механика и расчет сооружений, 1981, №3, с. 15-20.

3. Гольденблат И.И. Копнов В.А. Критерии прочности и пластичности конструкционных материалов. - М.: Издательство «Машиностроение», 1968. $191 \mathrm{c}$.

4. Езепов Г.Г. Прочность древесины при двухосном напряженном состоянии. Диссертация на соискание ученой степени кандидата технических наук по специальности 01.02.04 - «Механика деформируемого твердого тела». - М., 1986. - 142 c.

5. Орлович Р.Б., Езепов Г.Г., Найчук А.Я. К оценке некоторых критериев прочности анизотропных тел при плоском напряженном состоянии. // «Техника, технология, организация и экономика строительства». Республиканский межведомственный сборник. - Выпуск 10: «Строительная механика и строительные конструкции. - Минск: Вышейшая школа, 1984, с. 124-127.

6. Пятикрестовский К.П., Хунагов Х.С. Перераспределение усилий в элементах шатровой оболочки из древесины и фанеры при несимметричных нагрузках. // В книге Исследования и методы расчета строительных конструкций. - M.: ЦНИИСК им. В.А. Кучеренко, 1985, с. 40-49.

7. Флаксерман А.Н. Влияние наклона волокон на механические свойства древе- сины сосны. Тр. ЦАГИ, вып. 78, ГОНТИ, М.-Л., 1931г. - с. 48.

8. Гениев Г.А., Курбатов А.С. О предельных прочностных зависимостях для анизотропных материалов при сдвиге. // Методы расчета и оптимизации строительных конструкций на ЭВМ. - М.: ЦНИИСК им. Кучеренко, 1990, с. 60-67.

9. Гениев Г.А., Курбатов А.С., Самедов Ф.А. Вопросы прочности и пластичности анизотропных материалов. - М.: Интербук, 1993. - 187 с.

10. Гениев Г.А., Пятикрестовский К.П. Вопросы длительной и динамической прочности анизотропных конструкционных материалов. - М.: ГУП ЦНИИСК им. В.А. Кучеренко, 2000. - 38c.

11. Пятикрестовский К.П., Соколов Б.С. Нелинейный расчет статически неопределимых деревянных конструкций и оптимизация размеров сечений ребер куполов. // Сб. тезисов VII Международного симпозиума «Актуальные проблемы компьютерного моделирования конструкций и сооружений», Новосибирск, 2018.

12. Пятикрестовский К.П. Расчет ребристых пространственных конструкций из древесины и фанеры на длительные нагрузки. // Строительная механика и расчет сооружений, 2008, №5, с. 42-48

13. Леонтьев Н.Л. Упругие деформации древесины. - М.: Гослесбумиздат, 1952. $-120 \mathrm{c}$.

14. Леонтьев Н.Л. Длительное сопротивление древесины. - М.-Л.: Гослесбумиздат, 1957. - 132c.

15. Зайцев Ю.В. Моделирование деформаций и прочности бетона методами механики разрушения. - М.: Стройиздат, 1982. - $160 \mathrm{c}$.

Пятикрестовский Константин Пантелеевич, доктор технических наук, старший научный сотрудник, главный научный сотрудник Центрального научноисследовательского института строительных конструкций им. В.А. Кучеренко Акционерного общества 
«Научно-исследовательский центр «Строительство», 109428, г. Москва, 2-я Институтская улица, дом 6, корп.1; тел. +7 (499) 170-10-81; +7(499)170-15-48;

E-mail: stroymex@list.ru.

Соколов Борис Сергеевич, кандидат технических наук, заведующий лабораторией Научноисследовательского, проектно-конструкторского и технологического института бетона и железобетона (НИИЖБ) им. А.А. Гвоздева Акционерного общества «НИЦ «Строительство», тел. +7 (499) 174-74-80;

E-mail: moo-shell@mail.ru.

Konstantin P. Pyatikrestovsky, Dr.Sc., Senior Researcher, Executive Researcher of the TsNIISK named after V.A. Kucherenko, JSC Research Center of Construction; 109428, Russia, Moscow, 2-nd Institutskaya Street., 6; phone: +7 (499) 170-10-81; +7 (499) 170-15-48;

E-mail: stroymex@list.ru.

Boris S. Sokolov, Ph.D. in Engineering, Head of the Laboratory for thin-walled and spatial structures, Research and Design Institute for Concrete and Reinforced Concrete (NIIZhB) named after A.A. Gvozdev, JSC Research Center of Construction, Moscow.

phone: +7 (499) 174-74-80;

E-mail: moo-shell@mail.ru. 